\title{
Political ecologies of time and temporality in resource extraction
}

\author{
Ashley Fent ${ }^{1}$ \\ Erik Kojola \\ Vassar College, USA \\ Texas Christian University, USA
}

\begin{abstract}
This article introduces a Special Section on time and temporality in natural resource extraction. The Special Section illuminates the importance of both resource temporalities and temporal strategies around resource extraction, including nostalgia and identity, political strategies to delay projects, and contested attempts at predicting and managing the future. In addressing these themes, contributors highlight divergent spatiotemporalities and memories of extractive landscapes, local people's anticipation of future effects from mining, and governmental and corporate practices to speed up project implementation. We suggest that various temporal aspects - such as history, memory, velocity, delay, and epistemologies of time - play a central role in how struggles and controversies over extractive development manifest in particular places. We also offer additional avenues for research on contested understandings of time and temporality in political ecology.
\end{abstract}

Keywords: natural resources, extractive industry, temporality, political ecology

\section{Résumé}

Cet article présente une section spéciale sur le temps et la temporalité dans l'extraction des ressources naturelles. Les auteurs mettent en lumière l'importance à la fois des temporalités des ressources et des stratégies temporelles autour de l'extraction des ressources, y compris la nostalgie et l'identité, les stratégies politiques pour retarder les projets et les tentatives contestées de prédire et de gérer l'avenir. En abordant ces thèmes, les contributeurs mettent en évidence des spatio-temporalités et des souvenirs divergents des paysages extractifs, l'anticipation des effets futurs de l'exploitation minière par les populations locales, et les pratiques gouvernementales et corporatives utilisées pour accélérer la mise en œuvre des projets. Nous suggérons que divers aspects temporels - tels que l'histoire, la mémoire, la vitesse, le retard et les épistémologies du temps jouent un rôle central dans la façon dont les luttes et les controverses sur le développement extractif se manifestent dans des lieux particuliers. Nous proposons également des pistes de recherche supplémentaires sur les interprétations contestées du temps et de la temporalité en écologie politique.

Mots clés: ressources naturelles, industrie extractive, temporalité, écologie politique

\section{Resumen}

Este artículo presenta una sección especial sobre el tiempo y la temporalidad en la extracción de recursos naturales. Esta sección especial ilustra la importancia tanto de las temporalidades de los recursos, como de las estrategias temporales en la extracción de recursos, incluyendo nostalgia e identidad, estrategias políticas para retrasar proyectos, e intentos cuestionados al predecir y gestionar el futuro. Al abordar estos temas, los

\footnotetext{
${ }^{1}$ Dr. Ashley Fent, Postdoctoral Fellow, Earth Science and Geography Department, Vassar College, USA. Email: afent "at" vassar.edu. Dr. Erik Kojola, Assistant Professor, Department of Sociology and Anthropology, Texas Christian University, USA. Email: E.Kojola "at" tcu.edu. Acknowledgments: This introduction, and the Special Section of which it is a part, reflect equal authorship and an equal distribution of labor. We are grateful to the 2018 Dimensions of Political Ecology conference, which provided us with an opportunity to collaborate in our thinking about the issues that form the basis of this introductory article and Special Section. We also wish to thank the Editors of the Journal of Political Ecology, Prof. Casey Walsh and Prof. Simon Batterbury, for their comments and feedback on earlier drafts of this introduction. This is the Introduction to Ashley Fent and Erik Kojola (eds.) 2020. "Political Ecologies of Time and Temporality in Resource Extraction", Special Section of the Journal of Political Ecology 27: 819-938.
} 
colaboradores destacan las espacio-temporalidades divergentes y las memorias en entornos de minería, la previsión de poblaciones locales sobre los efectos de la minería, y la prácticas gubernamentales y corporativas para acelerar la implementación de proyectos. Sugerimos que varios aspectos temporales -como historia, memoria, velocidad, retraso y epistemología del tiempo- juegan un papel primordial en cómo los obstáculos y las controversias acerca del desarrollo extractivista se manifiestan en lugares específicos. También ofrecemos posibilidades alternativas para la investigación en interpretaciones debatidas sobre tiempo y la temporalidad en ecología política.

Palabras clave: recursos naturales, industria extractiva, temporalidad, ecología política

\section{Introduction}

Creating meaning and accumulating value from natural resources involves multiple economic, cultural, political, and biophysical processes, which occur over different timescales. Investments in resource extraction involve estimates of future reserves and profits, in order to make projects appear viable in the present. Divergent temporalities - of crop cycles, biogeochemical processes, or highly mobile forms of offshore oil extraction, for example - are important in converting aspects of nonhuman nature into resources and enrolling them in economic circuits. Extractive projects seek to streamline these different timescales, producing new tensions and discrepancies in the process. Furthermore, regulatory assessments of potential risks from resource extraction model future impacts in order to encourage mitigation. These seemingly technical predictions and calculations are imbued with power and politics; cultural understandings and ideologies shape how people interpret these calculations and whether they consider them legitimate. Resource extraction is thus an important site of struggle. Different groups mobilize divergent visions of the past and future to support or oppose extractive projects. Activists opposed to extraction may also mobilize various spatial and temporal strategies to delay and indefinitely postpone projects, while proponents call upon the economic urgency of moving forward with extraction.

Despite these temporal dynamics in the creation and extraction of resources, little political ecology scholarship has expressly addressed the temporal politics of natural resource extraction; instead, there has been more focus on the spatial and territorial dynamics and struggles over access and control of land, water, habitat, ancestral domain, and the subsurface. This Special Section of the Journal of Political Ecology brings research on temporality into conversation with political ecology, critical resource studies, and environmental history, as well as with geographic approaches to space and place.

The articles in this Special Section draw on sustained ethnographic engagement in locations in the global North and global South, and they explore diverse resource types. Focusing on the material and ideological practices involved in resource extraction, they show how the temporalities of natural resources animate diverse political-economic projects, how people use time as a political strategy, and how foreshortened timescales contribute to multiple environmental crises, including climate change, resource depletion, and loss of clean water. Some of the articles examine the political importance of nostalgia and future imaginaries around resources, while others demonstrate the importance of temporality in processes of capital accumulation, dispossession, and environmental mitigation. Overall, they use temporality as a framework for understanding the socio-ecological dynamics of natural resources and for assessing the role of power and ideology in the politics of extraction.

\section{Political ecologies of resources and temporality}

\section{Political ecology of natural resource extraction}

With its distinct approach to thinking through webs of human and nonhuman natures, political ecology is well positioned to examine material dynamics that are often excluded in other analyses of extraction politics. Natural resources, including metals, fossil fuels, water, and timber, are essential materials for capitalism and the construction of the global economy (McNeil and Vrtis 2017; Smil 2017). In the process of resource-making, nature is converted into property and is made valuable through the exclusion of other uses and users (Cronon 
1991, 1996; Rousselin 2018). As such, the expropriation of natural resources exemplifies accumulation by dispossession, which involves the use of extra-economic coercion and violence to free up land and resources for capital (Cronon 1983; Glassman 2006; Harvey 2003; Holden, Nadeau and Jacobson 2011). Numerous scholars interested in resource extraction have accordingly emphasized the establishment of certain kinds of property regimes for the subsurface, noting variations in how colonial powers and independent states have accorded these rights (Avalos-Lozano and Aguilar-Robledo 2017; Emel, Huber and Makene 2011) and how resource extraction has reshaped scales of jurisdiction and property ownership, transportation, and labor relations (Andrews and McCarthy 2014; Huber and Emel 2009; McNeil and Vrtis 2017; Morse 2003). Scholars have also highlighted the material effects of extraction on landscapes, regions, and biophysical properties of the Earth, in modern-day contexts and over longer historical periods (Bebbington 2012; Himley 2014; Isenberg 2005; Kirsch 2014; Klinger 2017; Langston 2017; Perreault 2013).

Extraction raises important questions about geographical relationships between states, affected communities, transnational corporations, and end users. Fossil fuels in particular are central for energizing and powering global capitalism through cheap energy and providing a source of profits through extraction and speculation (Huber 2013; Malm 2016; Moore 2015; Smil 2017); control over these resources has also been bound up in imperialist expansion (Mitchell 2013). Because of how extractive accumulation perpetuates ongoing forms of colonialism and the dispossession of Indigenous peoples, struggles for resource sovereignty have emerged in response; these have been articulated through diverse ideologies, ranging from nationalism to anti-colonialism (Partridge 2016). Yet because of the economic importance of extraction, many struggles to nationalize extractive industries have created problematic tensions in terms of states' simultaneous commitments to respect Indigenous rights and to attract investments (Bebbington and Humphreys Bebbington 2011).

Political ecology research on extraction has also engaged questions of socio-political conflict, including struggles over who makes decisions about extractive development and who faces the risks and consequences of environmental disruptions (Walter and Urkidi 2017). Scholarship has explored diverse forms of opposition to extractive development and has characterized the defense of communal resources and lands as a form of environmental justice activism (Bustos, Folchi and Fragkou 2017; Kojola 2019; Urkidi and Walter 2011; Velicu and Kaika 2017). Importantly, various dimensions of environmental justice - such as the distribution of environmental impacts, the procedural inclusion of stakeholders in decision-making, and the recognition of Indigenous peoples - may be mobilized and emphasized in different stages of extractive projects (Urkidi and Walter 2011).

\section{Temporality}

The interdisciplinarity of political ecology means that the field is well-situated to apply temporal analysis to the politics of nature. Time has been defined as the "phenomenon of becoming," and temporality as the "interpretation of becoming" (Iparraguirre 2016: 614). Temporality is thus a conceptual and interpretive framework that helps in understanding the production of social meaning and culture, processes of capital accumulation, and political strategies (Boym 2001; Davis 1979; Jones and Garde-Hansen 2012; Lipsitz 1990). It captures the myriad ways that time is experienced, apprehended, and mobilized toward certain ends. Understandings of time are actively constructed and do political work, naturalizing dominant social relations or activating counter-hegemonies.

Control over time has been critical to the functioning of capitalism and colonialism. Capitalism relies on the construction of measurable and linear time to discipline workers and assign value to wage labor, yet these temporalities are also resisted and contested by workers (Castree 2009; Harvey 1982; Massey 1999; Rifkin 2017; Thompson 1964). Additionally, through inventions such as railroad schedules, capitalism standardized previously eclectic, local, and personal measures of time (Cronon 1991). Colonialism also depends on the calculability and disciplinary power of linear temporalities for governance and control of land, resources, and populations (Rifkin 2017). Colonial subjugation was legitimized through Orientalist ideologies that portrayed people in the global south as "backward" and thus out of sync with modern time (Adam 2006; Morse 2003). Critiques of the colonial underpinnings of anthropology have likewise articulated what has been termed 
"allochronism" or the "denial of coevalness" - the treatment of ethnographic subjects as existing in a different and past spatio-temporal frame that operates beyond the flow of modern time (Fabian 1983).

Yet time is also a site of political struggle. Against the hegemonic power of capitalism and colonialism to normalize, dehistoricize, and generalize their own temporalities, a plurality of alternative temporalities still operate (Donaldson 1996). Varied cultural and political-economic contexts shape social organizations and perceptions of time (Munn 1992; Rutz 1992), as well as the material conditions of resource use. Contestations over time are one way that Indigenous people continue to claim sovereignty and understand socio-ecological and political relations through alternative temporalities (Rifkin 2017). In some cases, Indigenous temporalities may coexist in hybrid forms with hegemonic temporalities (Iparraguirre 2016); in other cases, they may be mobilized to defy and resist settler colonialism (Rifkin 2017). These struggles inform a growing field of scholarship and activism around the notion of temporal justice, in relation to decision-making, land and resource governance, and Indigenous sovereignty (Goodin 2010). Beyond Indigenous struggles, wider attempts to challenge neoliberal capitalism have also drawn upon the material and visceral practices of slowness, in both academic work (Mountz et al. 2015) and food movements (Hayes-Conroy and Hayes-Conroy 2010).

The globalization of capital and its attendant "time-space compression" (Harvey 1990) have produced new temporal disjunctures, inequalities, and experiences. Time-space compression reworks Marx's conception of the annihilation of space through time, in which innovations in communications and transportation collapse geographical space by enabling increasingly rapid transactions across vast distances. As David Harvey suggests, space is not annihilated but is rather produced anew through innovations that reduce the friction of distance; these processes "so revolutionize the objective qualities of space and time that we are forced to alter, sometimes in quite radical ways, how we represent the world to ourselves" (Harvey 1990: 240). Time-space experiences and representations are thus continually constructed in the accumulation process and resistances to it.

Geographers have often emphasized the spatial dynamics at stake in what Doreen Massey (1991, 1999) terms "power geometry" - a corrective view of time-space compression that highlights different mobilities and connections across space. However, these spatial dynamics go hand in hand with divergent experiences of time, speed, and futurity. For instance, the production of global simultaneity through digital technology has been made possible by the "temporal dispossession" of coltan miners in the eastern Democratic Republic of Congo, through which the violent political economy of coltan - used in electronic devices - renders ordinary people unable to predict or plan for the future (Smith 2011). The technologies that have been so ubiquitous and central to globalization's time-space compression also produce ecological devastation, structural violence, and foreclosure of the future in this and other regions (Klinger 2017; Smith 2011).

Scholars have challenged conceptual divisions between space and time (May and Thrift 2001). In response to the spatial turn in the social sciences (Lefebvre 1991; Massey 1992; Urry 1991), geographers have introduced concepts such as the "spatio-temporal fix" and have emphasized spatio-temporality or space-time, as a co-constituted entity whose manipulation is central to capitalist processes (Castree 2009; Jessop 2006). This collection of articles builds on this existing scholarship, which suggests that temporality is spatial and spatiality is temporal (Massey 2018).

\section{Temporalities of natural resource extraction}

An emerging area in political ecology scholarship explores the temporal dynamics of how resources are produced and how social actors understand and use nonhuman nature (Ferry and Limbert 2008; Li 2017; Szolucha 2018; Weszkalnys 2014). Building on this work, the articles in this Special Section use political ecology approaches to theorize the multiple timescales involved in resource-making and extraction. Articles address two distinct but related aspects of temporality: the temporalities of resources, and the temporal politics and strategies surrounding resource extraction, such as temporal emotions and identities, the use of time as a political strategy, and divergent temporalities involved in impact assessment and predictive calculations.

\section{Material temporalities}

Biophysical and ecological timescales shape the politics of resource extraction and demonstrate the interconnections between human and nonhuman natures. The tangible matter of resources is produced through 
geological and ecological processes whose timescales are much longer than the social and economic timescales used in defining, valuing, and consuming these resources (Ferry and Limbert 2008). For example, fossil fuels have been consumed more rapidly in the past two hundred years than bio-geophysical processes can create them, over hundreds of millions of years. Similarly, other types of minerals formed over long geological timescales have been rapidly and rapaciously depleted. The speed of extraction is also constrained by the physical location of subterranean resources and their chemical properties (Kohl and Farthing 2012; Richardson and Weszkalnys 2014; Widick 2009); some materials, such as bituminous tar sands, are so difficult to extract that they require copious amounts of other nonrenewable resources in order to do so. This compels greater attention to divergent timescales and temporalities in socio-political interactions with the geophysical and biophysical world (Arnall and Kothari 2015; Clark and Gunaratnam 2017; Li 2017).

Additional work on divergent temporalities highlights the role of epistemology, suggesting that the timescales of Western and colonial scientific observation have often failed to grasp processes that occur over long periods of geological and ecological time (Duvall 2011). For example, drawing on Anishinaabe temporalities and contrasting these with Western observations and measurements of time, Sâkihitowin Awâsis's article in this Special Section explores how Indigenous temporalities are necessarily connected to materialities and intertwined with nonhuman animals, seasons, land, and myriad ecological and planetary processes (Awâsis 2020). Multiple Anishinaabe temporalities are connected to land and are made through and with nature, challenging divisions between time and space.

\section{Time as political strategy}

Time is also a source of struggle and political-economic strategizing. Historically, certain extractive monopolies - such as oil companies - have stalled, delayed, or refused to develop resource discoveries, in order to manipulate supply and price (Mitchell 2013). This has led to struggles over resource development, often at the national level. More broadly, extractive inertia and strategic manipulations of materiality and velocity continue to be important in resource politics (Hitchcock 2015).

For their part, activists often work to delay mining development and mobilize competing visions of the past and future in debates over energy production (Hébert 2016; Kirsch 2014; Kneas 2016; Labussière and Nadaï 2018; Szolucha 2018). In some cases, opponents of resource extraction have slowed down and delayed production through physically blocking extractive development or dragging out regulatory approval processes (Gedicks 1993). In other cases, labor cooperatives have sought to slow down the production process of existing mining operations, in order to ensure longer-term job security and the continuation of the resource as part of national patrimony (Ferry 2005). This is reminiscent of theorizations of how both activists and mining corporations mobilize the "politics of time" to their advantage (Kirsch 2014). Ashley Fent's article in this Special Section mobilizes the idea of anticipatory politics to show how local actors opposing a mining project in Casamance, Senegal, intervene in the present to produce delays and to stake claims to an increasingly uncertain future (Fent 2020). Delays can be particularly disruptive for companies whose investments depend on fluctuating global commodity markets. As a result, this potential for disruption has compelled a series of corporate and governmental strategies to eliminate social frictions (Kirsch 2014; Li 2015). In part, this has occurred through producing new kinds of spatio-temporal arrangements, as exemplified by modular, flexible, and socio-politically "disentangled" offshore oil rigs (Appel 2012; Ferguson 2005).

Extractive companies also use time to secure consent by promoting imaginaries of future abundance, and distancing extractive practices from potential environmental pollution, social and economic disruptions, and long-term human health impacts (Kojola 2020). In cases where popular consent is mandated, the approval of new extractive projects, from oil pipelines to sand mines, requires cultivating a sense of public trust and security. The building of trust is a temporal process, and it often becomes a site of contestation between different visions of the future and prediction of risks and benefits (Mayer 2016; Szolucha 2018).

\section{Temporal emotions and identities}

Affective temporal frames are also mobilized in remembering, experiencing, or planning for resource extraction (McNeil and Vrtis 2017; Ferry and Limbert 2008; Weszkalnys 2014, 2015). The politics of resource 
extraction are intertwined with positive and negative memories and dispositions toward the future. Romantic and idyllic forms of nostalgia are a socially productive way of articulating the past in the present, rather than reflecting an objective or passive memory of the past. Nostalgic interpretations of the past are mobilized to support often paradoxical approaches to new forms of extraction. For instance, debates within coal mining towns about mountaintop removal mobilize contradictory aspects of the role of nature and work in local historically-rooted identities (Scott 2010; Smith 2015). Focusing on proposed copper mines in Minnesota, Erik Kojola's (2020) contribution explores the multidimensionality of memory and identity, as well as the emotions that are mobilized through appeals to the past and future imaginaries. He shows how opponents and supporters of mining development mobilize different class- and place-based timescapes to legitimate their positions, encouraging greater attention to historical power relations and the ways that different memories of the past influence affective dispositions in present controversies. Nostalgic collective memories and hopeful environmental imaginaries are powerful emotions that reproduce hegemonic extractivism, but alternative timescapes connected to conservation and recreation can also disrupt the inevitability of extraction.

The articles included in this Special Section also demonstrate how identities related to place, indigeneity, race, labor, and gender are informed by emotional connections to the histories of extraction. In his contribution, Alessandro Morosin (2020) finds that collective memories and past experiences motivate Indigenous community resistance to development plans in Oaxaca's Isthmus of Tehuantepec. Indigenous activists and campesinos draw on stories of both trauma and solidarity in the face of state repression to articulate a new kind of defense of their territory and identities, against extractive development led by foreign capital and supported by Mexican elites.

These processes disrupt conventional divisions of time, showing how the past, present, and future are co-constituted. Awâsis (2020) expresses this explicitly, showing how Anishinaabe time does not adhere to the divisions of Western colonial time - which emphasize past, present, and future - but instead embraces temporal interconnections and fluidity. More broadly, the contributors highlight multiple ways in which temporal identities, collective memories, and future imaginaries may be conceived, including but not exclusively limited to linear understandings of time.

\section{Assessing and predicting the future}

Temporality is also central to creating value in extractive industries and assessing environmental risks and hazards. Speculation in extractive infrastructure projects and global commodity prices construct futures markets for natural resources (Gilbert 2016; Labban 2010; Weszkalnys 2015), and the value of resources depends on temporalities, flows, and blockages in extraction, storage, and transportation. For instance, agricultural commodities have a limited shelf-life, while metals and fossil fuels can be stored indefinitely, enabling stockpiling and strategic maneuvers to influence prices by releasing or withholding materials from the market (Adkins 2009; Mitchell 2013). Additionally, technical, engineering, and scientific techniques are used to assess potential reserves and create a vision of certainty, abundance, and profitability (Mitchell 2013; Szolucha 2018) amid the "radical incalculability" of highly economically irrational markets and "boom and bust" cycles (Appel, Mason and Watts 2015: 9). As Yvonne Braun's article (2020, in this Special Section) on large dams in the Lesotho Highlands Water Project shows, projects may acquire legitimacy by dividing investments into distinct phases, engaging in cycles of disinvestment and reinvestment, and structurally neglecting the negative effects from prior construction work.

The process of environmental and social impact assessment is also an important site of prediction about future ecological, social, and economic effects from extraction, as well as a site of leverage and contestation (Bedi 2013; Gramling and Freudenberg 1991; Kirsch 2014; F. Li 2015; McCreary, Mills and St. Amand 2016; Spiegel 2017; Vanclay 2012). Moving beyond earlier approaches to assessment that focused exclusively on environmental concerns, more collaborative and participatory forms of social impact assessment can facilitate more democratic decision-making and holistic understandings of complex socio-ecological relations; however, assessment remains contested and is shaped by power relations between mining companies, states, workers, and residents (Harvey and Bice 2014; Vanclay 2012; Vanclay and Bronstein 1995; Vanclay and Esteves 2011). These bureaucratic models for public consultation and ecological and socio-economic consideration also have 
their own temporalities, which are often at odds with the timescales upon which processes and effects occur. As Awâsis (2020) shows, pipeline review and assessment timelines, modeled on settler-colonial and capitalistic temporal frameworks, erase and undermine Indigenous Anishinaabe spatio-temporalities, such as seasonality and intergenerational and nonhuman relations. Fent's article (2020) also addresses how the environmental review process can become a site of contestation, as scientific experts offer assessments of future risks, while anti-mine activists use public consultation processes to produce delay, debate, and alternative predictions about anticipated environmental and social effects from mining.

\section{Conclusion}

The articles in this Special Section highlight the importance of considering multiple and divergent spatiotemporalities in resource politics. They show that geographically, historically, and culturally specific approaches to the past - such as nostalgia, collective memory, and histories of marginalization and oppression - condition communities' visions of extractive futures in different ways, and are mobilized toward contemporary political projects. They also suggest that temporal strategies are used by differently situated actors to produce delay, engage in anticipatory action, or speed up the process of land and resource expropriation. Further research on this topic could work across various projects and contexts to understand the factors that affect the success or failure of these spatio-temporal strategies in particular places. This work could also engage in relational comparisons among these movements, examining their similarities, differences, and potential linkages with each other.

Additionally, most of the ethnographic work presented in this Special Section engages primarily with affected communities. In keeping with existing work that examines corporate perspectives and labor arrangements in these spheres (Appel 2012), as well as national government planning and geological exploration (Weszkalnys 2014, 2015), there is room for additional research that would understand how contemporary practices by states, corporations, banks, and scientists also influence the temporalities of project approval and implementation.

Throughout this Special Section, articles disrupt the taken-for-granted divisions between past, present, and future - and between time and space, demonstrating how these are fluid and interconnected. They show that understandings of the past inform projections of the future and motivate actions in the present; they also highlight the importance of collective memory and the iterative ways that socio-ecological histories are apprehended. Furthermore, they suggest that spaces of extraction turn into sites of capital accumulation and/or of popular protest through temporal processes of remembering, predicting, anticipating, and visioning.

In taking materiality and more-than-human interactions seriously, the articles also address divergent timescales through which resources are formed, used, and extracted. They suggest that environmental and social impact review processes often occur on timescales that do not fully allow for observation of longer-term effects, and marginalize other temporalities through which various socio-ecological processes occur and through which humans apprehend these processes.

We suggest there is room for additional research within political ecology about divergent temporal epistemologies and the timescales of resources themselves. This could work to further decenter and provincialize colonial and capitalist understandings of time; it could also illuminate diversity in how time operates and is experienced, both with reference to resource use and more broadly.

\section{References}

Adam, B. 2006. Time. Theory, Culture and Society 23(2-3): 119-126.

Adkins, L. 2009. Sociological futures: from clock time to event time. Sociological Research Online 14(4): 15.

Andrews, E. and J. McCarthy. 2014. Scale, shale, and the state: political ecologies and legal geographies of shale gas development in Pennsylvania. Journal of Environmental Studies and Sciences 4(1): 7-16.

Appel, H. 2012. Offshore work: oil, modularity, and the how of capitalism in Equatorial Guinea. American Ethnologist 39(4): 692-709. 
Appel, H., A. Mason and M.J. Watts. 2015. Introduction: oil talk. In Appel, H., A. Mason and M.J. Watts (eds.). Subterranean estates: life worlds of oil and gas. Ithaca, NY: Cornell University Press. Pp. 1-26.

Arnall, A. and U. Kothari. 2015. Challenging climate change and migration discourse: different understandings of timescale and temporality in the Maldives. Global Environmental Change 31: 199-206.

Avalos-Lozano, A. and M. Aguilar-Robledo. 2017. Reconstructing the environmental history of colonial mining: the Real Del Catorce mining district, northeastern New Spain/Mexico, eighteenth and nineteenth centuries. In McNeil, J.R. and G. Vrtis (eds.). Mining North America: an environmental history since 1522. Oakland, CA: University of California Press. Pp. 47-72.

Awâsis, S. 2020. "Anishinaabe time": temporalities and impact assessment in pipeline reviews. Journal of Political Ecology 27: 830-852.

Bebbington, A.J. 2012. Underground political ecologies: the second annual lecture of the Cultural and Political Ecology Specialty Group of the Association of American Geographers. Geoforum 43 (6): 1152-1162.

Bebbington, A.J. and D. Humphreys Bebbington. 2011. An Andean avatar: post-neoliberal and neoliberal strategies for securing the unobtainable. New Political Economy 16(1): 131-145.

Bedi, H.P. 2013. Environmental mis-assessment, development and mining in Orissa, India. Development and Change 44 (1): 101-123.

Boym, S. 2001. The future of nostalgia. New York: Basic Books.

Braun, Y.A. 2020. Lesotho's white gold: the political ecology of temporality and the economy of anticipation in resource extraction and large dam infrastructural project. Journal of Political Ecology 27: 853-876.

Bustos, B., M. Folchi and M. Fragkou. 2017. Coal mining on pastureland in southern Chile: challenging recognition and participation as guarantees for environmental justice. Geoforum 84: 292-304.

Castree, N. 2009. The spatio-temporality of capitalism. Time \& Society 18 (1): 26-61.

Clark, N. and Y. Gunaratnam. 2017. Earthing the Anthropos? From 'socializing the Anthropocene' to geologizing the social. European Journal of Social Theory 20: 146-163.

Cronon, W. 1983. Changes in the land: Indians, colonists, and the ecology of New England. New York: Hill \& Wang.

Cronon, W. 1991. Nature's metropolis: Chicago and the Great West. New York: W.W. Norton \& Company.

Cronon, W. 1996. Uncommon ground: rethinking the human place in nature. New York: W.W. Norton \& Company.

Davis, F. 1979. Yearning for yesterday: a sociology of nostalgia. New York: Free Press.

Donaldson, M. 1996. The end of time? Aboriginal temporality and the British invasion of Australia. Time \& Society 5 (2): 187-207.

Duvall, C. 2011. Ferricrete, forests, and temporal scale in the production of colonial science in Africa. In Goldman, M.J., P. Nadasdy and M.D. Turner (eds.). Knowing nature: conversations at the intersection of political ecology and science studies. Chicago: University of Chicago Press. Pp. 113-127.

Emel, J., M.T. Huber and M.H. Makene. 2011. Extracting sovereignty: capital, territory, and gold mining in Tanzania. Political Geography 30: 70-79.

Fabian, J. 1983. Time and the other: how anthropology makes its object. New York: Columbia University Press.

Fent, A. 2020. The anticipatory politics of dispossession in a Senegalese mining negotiation. Journal of Political Ecology 27: 877-897.

Ferguson, J. 2005. Seeing like an oil company: space, security, and global capital in neoliberal Africa. American Anthropologist 107 (3): 377-382.

Ferry, E.E. 2005. Not ours alone: patrimony, value, and collectivity in contemporary Mexico. New York: Columbia University Press.

Ferry, E.E. and M.E. Limbert. 2008. Timely assets: the politics of resources and their temporalities. Santa Fe: School for Advanced Research Press. 
Gedicks, A. 1993. The new resource wars: Native and environmental struggles against multinational corporations. Boston: South End Press.

Gilbert, P.R. 2016. Money mines: an ethnography of frontiers, capital and extractive industries in London and Bangladesh. Ph.D. dissertation. Brighton: University of Sussex.

Glassman, J. 2006. Primitive accumulation, accumulation by dispossession, accumulation by 'extra-economic' means. Progress in Human Geography 30(5): 608-625.

Goodin, R.E. 2010. Temporal justice. Journal of Social Policy 39(1): 1-16.

Gramling, R. and W.R. Freudenburg. Opportunity-threat, development, and adaptation: toward a comprehensive framework for social impact assessment. Rural Sociology 57(2): 216-234.

Harvey, B. and S. Bice. 2014. Social impact assessment, social development programmes and social licence to operate: tensions and contradictions in intent and practice in the extractive sector. Impact Assessment and Project Appraisal 32(4): 327-335.

Harvey, D. 1982. The limits to capital. Chicago: University of Chicago Press.

Harvey, D. 1990. The condition of postmodernity: an enquiry into the origins of cultural change. Oxford: Blackwell.

Harvey, D. 2003. The new imperialism. Oxford: Oxford University Press.

Hayes-Conroy, A. and J. Hayes-Conroy. 2010. Visceral difference: variations in feeling (slow) food. Environment and Planning A: Economy and Space 42(12): 2956-2971.

Hébert, K. 2016. Chronicle of a disaster foretold: scientific risk assessment, public participation, and the politics of imperilment in Bristol Bay, Alaska. Journal of the Royal Anthropological Institute 22(S1): 108-126.

Holden, W., K. Nadeau and R.D. Jacobson. 2011. Exemplifying accumulation by dispossession: mining and indigenous peoples in the Philippines. Geografiska Annaler: Series B, Human Geography 93(2): 141161.

Himley, M. 2014. Monitoring the impacts of extraction: science and participation in the governance of mining in Peru. Environment and Planning A: Economy and Space 46(5): 1069-1087.

Hitchcock, P. 2015. Velocity and viscosity. In Appel, H., A. Mason and M.J. Watts (eds.). Subterranean estates: life worlds of oil and gas. Ithaca: Cornell University Press. Pp. 45-60.

Huber, M.T. 2013. Lifeblood: oil, freedom, and the forces of capital. Minneapolis: University of Minnesota Press.

Huber, M.T. and J. Emel. 2009. Fixed minerals, scalar politics: the weight of scale in conflicts over the '1872 Mining Law' in the United States. Environment and Planning A 41(2): 371-388.

Iparraguirre, G. 2016. Time, temporality and cultural rhythmics: an anthropological case study. Time \& Society 25(3): 613-33.

Isenberg, A.C. 2005. Mining California: an ecological history. New York: Farrar, Straus and Giroux.

Jessop, B. 2006. Spatial fixes, temporal fixes, and spatio-temporal fixes. In Castree, N. and D. Gregory (eds.). David Harvey: a critical reader. Oxford: Blackwell. Pp. 142-166.

Jones, O. and J. Garde-Hansen. 2012. Geography and memory: explorations in identity, place and becoming. New York: Palgrave Macmillan.

Kirsch, S. 2014. Mining capitalism: the relationship between corporations and their critics. Berkeley: University of California Press.

Klinger, J.M. 2017. Rare earth frontiers: from terrestrial subsoils to lunar landscapes. Ithaca: Cornell University Press.

Kneas, D. 2016. Subsoil abundance and surface absence: a junior mining company and its performance of prognosis in northwestern Ecuador. Journal of the Royal Anthropological Institute 22(S1): 67-86.

Kohl, B. and L. Farthing. 2012. Material constraints to popular imaginaries: the extractive economy and resource nationalism in Bolivia. Political Geography 31: 225-235. 
Kojola, E. 2019. Indigeneity, gender and class in decision-making about risks from resource extraction. Environmental Sociology 5(2): 130-148.

Kojola, E. 2020. Divergent memories and visions of the future in conflicts over mining development. Journal of Political Ecology 27: 898-916.

Labban, M. 2010. Oil in parallax: scarcity, markets, and the financialization of accumulation. Geoforum 41(4): $541-552$.

Langston, N. 2017. Sustaining Lake Superior: an extraordinary lake in a changing world. New Haven: Yale University Press.

Lefebvre, H. 1991[1974]. The production of space. Oxford: Blackwell.

Labussière, O. and A. Nadaï. 2018. The temporalities of energy transition processes. In Labussière, O. and A. Nadaï (eds.). Energy transitions: a socio-technical inquiry. New York: Palgrave MacMillan. Pp. 277317.

Li, F. 2015. Unearthing conflict: corporate mining, activism, and expertise in Peru. Durham: Duke University Press.

Li, T.M. 2017. Rendering land investible: five notes on time. Geoforum 82: 276-278.

Lipsitz, G. 1990. Time passages: collective memory and American popular culture. Minneapolis: University of Minnesota Press.

Malm, A. 2016. Fossil capital: the rise of steam power and the roots of global warming. New York: Verso.

Massey, D. 1991. A global sense of place. Marxism Today June: 24-29.

Massey, D. 1992. Politics and space/time. New Left Review 1(196): 65-84.

Massey, D. 1999. Power-geometries and the politics of space-time. Heidelberg: University of Heidelberg Press.

Massey, D. 2018. Politics and space time. In Christophers, B., R. Lave, J. Peck and M. Werner (eds.). The Doreen Massey reader. Newcastle upon Tyne: Agenda Publishing. Pp. 259-278.

May, J. and N. Thrift. 2001. Timespace: geographies of temporality. London: Routledge.

Mayer, A. 2016. Risk and benefits in a fracking boom: evidence from Colorado. The Extractive Industries and Society 3(3): 744-753.

McCreary, T., S. Mills and A. St-Amand. 2016. Lands and resources for jobs: how Aboriginal peoples strategically use environmental assessments to advance community employment aims. Canadian Public Policy 42(2): 212-223.

McNeil, J.R. and G. Vrtis (eds.). 2017. Mining North America: an environmental history since 1522. Berkeley: University of California Press.

Mitchell, T. 2013. Carbon democracy: political power in the age of oil. London: Verso.

Moore, J.W. 2015. Capitalism in the web of life: ecology and the accumulation of capital. London: Verso.

Morosin, A. 2020. Comunalidad, Guendaliza'a and anti-mine mobilizations in the Isthmus of Tehuantepec. Journal of Political Ecology 27: 819-938.

Morse, K.T. 2003. The nature of gold: an environmental history of the Klondike Gold Rush. Seattle: University of Washington Press.

Mountz. A., A. Bonds, B. Mansfield, J. Loyd, J. Hyndman, M. Walton-Roberts, R. Basu, R. Whitson, R. Hawkins, T. Hamilton and W. Curran 2015. For slow scholarship: a feminist politics of resistance though collective action in the neoliberal university. ACME: An International E-Journal for Critical Geographies 14 (4): 1235-1259.

Munn, N.D. 1992. The cultural anthropology of time: a critical essay. Annual Review of Anthropology 21: 93123.

Partridge, T. 2016. Rural intersections: resource marginalisation and the 'non-Indian problem' in highland Ecuador. Journal of Rural Studies 47: 337-349.

Perreault, T. 2013. Dispossession by accumulation? Mining, water and the nature of enclosure on the Bolivian Altiplano. Antipode 45 (5): 1050-1069. 
Richardson, T. and G. Weszkalnys. 2014. Introduction: resource materialities. Anthropological Quarterly 87(1): 5-30.

Rifkin, M. 2017. Beyond settler time: temporal sovereignty and Indigenous self-determination. Durham: Duke University Press.

Rousselin, M. 2018. A study in dispossession: the political ecology of phosphate in Tunisia. Journal of Political Ecology 25: 20-39.

Rutz, H.J. 1992. The politics of time. Washington, D.C.: American Anthropological Association.

Scott, R.R. 2010. Removing mountains: extracting nature and identity in the Appalachian coalfields. Minneapolis: University of Minnesota Press.

Smil, V. 2017. Energy and civilization: a history. Cambridge: MIT Press.

Smith, B.E. 2015. Another place is possible? labor geography, spatial dispossession, and gendered resistance in central Appalachia. Annals of the Association of American Geographers 105(3): 567-582.

Smith, J.H. 2011. Tantalus in the digital age: coltan ore, temporal dispossession, and 'movement' in the Eastern Democratic Republic of the Congo. American Ethnologist 38(1): 17-35.

Spiegel, S. J. 2017. EIAs, power and political ecology: situating resource struggles and the techno-politics of small-scale mining. Geoforum 87: 95-107.

Szolucha, A. 2018. Anticipating fracking: shale gas developments and the politics of time in Lancashire, UK. The Extractive Industries and Society 5(3): 348-355.

Thompson, E. P. 1964. The making of the English working class. New York: Pantheon Books.

Urkidi, L. and M. Walter. 2011. Dimensions of environmental justice in anti-gold mining movements in Latin America. Geoforum 42(6): 683-695.

Urry, J. 1985. Social relations, space and time. In Gregory, D. and J. Urry (eds.). Social relations and spatial structures. London: Macmillan Education. Pp. 20-48.

Vanclay, F. 2003. International principles for social impact assessment. Impact Assessment and Project Appraisal 21(1): 5-12.

Vanclay, F. and D. Bronstein (eds.). 1995. Environmental and social impact assessment. Chichester: Wiley.

Vanclay, F. and A.M. Esteves (eds.). 2011. New directions in social impact assessment: conceptual and methodological advances. Cheltenham: Edward Elgar.

Velicu, I. and M. Kaika. 2017. Undoing environmental justice: re-imagining equality in the Rosia Montana anti-mining movement. Geoforum 84: 305-315.

Walter, M. and L. Urkidi. 2017. Community mining consultations in Latin America (2002-2012): the contested emergence of a hybrid institution for participation. Geoforum 84: 265-279.

Weszkalnys, G. 2014. Anticipating oil: the temporal politics of a disaster yet to come. The Sociological Review 62 (1_suppl): 211-235.

Weszkalnys, G. 2015. Geology, potentiality, speculation: on the indeterminacy of first oil. Cultural Anthropology 30(4): 611-639.

Widick, R. 2009. Trouble in the forest: California's redwood timber wars. Minneapolis: University of Minnesota Press. 